\title{
The protease inhibitor $\mathrm{PI}{ }^{\star} \mathrm{S}$ allele and COPD: a meta-analysis
}

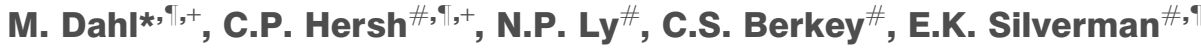 \\ and B.G. Nordestgaard*
}

ABSTRACT: In many countries, the protease inhibitor (SERPINA1) PI*S allele is more common than $\mathrm{PI}{ }^{\star} \mathrm{Z}$, the allele responsible for most cases of chronic obstructive pulmonary disease (COPD) due to severe alpha 1-antitrypsin deficiency. However, the risk of COPD due to the PI*S allele is not clear.

The current authors located studies that addressed the risk of COPD or measured lung function in individuals with the PI SZ, PI MS and PI SS genotypes. A separate meta-analysis for each genotype was performed.

Aggregating data from six studies, the odds ratio (OR) for COPD in PI SZ compound heterozygotes compared with PI MM (normal) individuals was significantly increased at 3.26 (95\% confidence intervals (CI): 1.24-8.57). In 17 cross-sectional and case-control studies, the OR for COPD in PI MS heterozygotes was 1.19 (95\% $\mathrm{Cl}$ : 1.02-1.38). However, PI MS genotype was not associated with COPD risk after correcting for smoking. Furthermore, mean forced expiratory volume in one second, a measure of airflow obstruction and a defining feature of COPD, did not differ between PI MS and PI MM individuals. There were not enough cases to summarise the risk of COPD in PI SS homozygotes.

In conclusion, the results show that the PI SZ genotype is a significant risk factor for chronic obstructive pulmonary disease. The risk of chronic obstructive pulmonary disease due to the PI MS genotype is not substantially elevated.

KEYWORDS: Alpha 1-antitrypsin, chronic obstructive pulmonary disease, emphysema, heterozygote, meta-analysis

0 evere alpha 1-antitrypsin (AAT) deficiency (OMIM 107400) is the most important known genetic risk factor for developing chronic obstructive pulmonary disease (COPD). AAT is a circulating serine protease inhibitor (PI) that protects lung parenchyma from the damaging effects of proteases, particularly neutrophil elastase. AAT is encoded by the PI locus (HUGO symbol; SERPINA1), located on chromosome $14 \mathrm{q}$ as part of a cluster of other serine protease inhibitor genes [1].

Severe AAT deficiency is usually caused by the presence of two copies of the mutant $Z$ allele. In most populations in which allele frequencies have been measured, the $S$ allele is the more common variant $[2,3]$. The $S$ mutation is thought to have arisen on the Iberian Peninsula, and has a different geographic distribution than the $\mathrm{Z}$ allele $[4,5]$. In the USA, the $S$ allele frequency is $2-4 \%$, compared with $1-2 \%$ for the $Z$ allele [2]. Only in northern European nations is the $Z$ allele the more common variant, reflecting the historical origin of the mutation [3].
Initial studies on the PI SZ genotype reported an increased risk of COPD associated with this variant [6]. Other studies have suggested that the increased risk is confined to smokers only [710]. However, these studies were all lacking in control subjects (PI MM), making an accurate risk estimate difficult.

The S allele (Glu264Val) leads to a reduction in plasma AAT concentration, although not to the same degree as the $Z$ allele $[11,12]$. Consequently, the PI MS genotype is usually not considered to carry an elevated risk for COPD. The recent American Thoracic Society (ATS) statement on AAT deficiency does not mention PI MS heterozygosity as a possible risk factor for COPD [13].

The current authors recently published a metaanalysis in PI MZ heterozygous individuals, finding an increased risk of COPD (odds ratio (OR): $2.31 ; 95 \%$ confidence intervals (CI): 1.60 3.35) [14]. However, there was no difference in pulmonary function, measured as the forced

\section{AFFILIATIONS}

*Dept of Clinical Biochemistry, Herlev University Hospital, Copenhagen, Denmark, and \#Channing Laboratory, and 'Division of Pulmonary and Critical Care Medicine, Dept of Medicine Brigham and Women's Hospital and Harvard Medical School, Boston MA, USA.

${ }^{+}$Authors contributed equally.

CORRESPONDENCE

M. Dahl

Dept of Environmental Health Harvard School of Public Health 665 Huntington Ave Boston MA 02115

USA

Fax: 16174324710

E-mail: mdahl@hsph.harvard.edu

Received:

November 282004

Accepted after revision: March 272005

\section{SUPPORT STATEMENT}

This study was supported by grants from the Danish Lung Association, Danish Heart Association (Copenhagen, Denmark), and by U.S. National Institutes of Health (Bethesda, MD, USA) grants T32HL07427 and R01-HL68926. 
expiratory volume in one second (FEV1), between PI MM and PI MZ individuals. The current authors now report a parallel analysis to examine the risk of COPD due to the PI*S allele. The present study attempted to address the following questions: 1) Is there an increased risk of COPD in individuals with genotypes PI SZ, PI MS, or PI SS? and, if so, 2) What are the magnitudes of the increased risk?

\section{MATERIAL AND METHODS Study selection}

Methods of the search strategy, study assessment and data analysis were similar to the present authors' previously published meta-analysis of PI MZ heterozygotes [14]. For the analysis of COPD risk due to the $\mathrm{PI}^{*} \mathrm{~S}$ allele, studies were identified through a search of MEDLINE, from January 1966 to May 2003, using the medical subject headings: alpha 1antitrypsin, alpha 1-antitrypsin deficiency, protease inhibitors, obstructive lung diseases, chronic obstructive pulmonary disease, pulmonary emphysema, forced expiratory volume, respiratory function tests and spirometry. Bibliographies of identified articles and reviews were searched for additional references. M. Dahl and C.P. Hersh independently assessed studies for inclusion. Discussion with E.K. Silverman was used to resolve disagreements.

Case-control and cross-sectional studies using the categorical outcome of COPD, based on pulmonary function tests or a physician's diagnosis, and studies reporting FEV1 per cent predicted as a continuous outcome measure were included. It was stipulated that PI type had to be determined using isoelectric focusing, acid starch gel with crossed immunoelectrophoresis, or a molecular genotyping method. In case-control designs, studies that used controls from a previously published report were included, as long as the cases and controls were from the same country and the same technique was used for assessment of PI type.

Exclusion criteria were as follows: 1) studies that inferred PI type from serum AAT levels, since genotypes could not be accurately determined; 2) family studies and studies of children only; 3 ) for the continuous outcome, studies that did not present FEV1 as a per cent of the predicted value; and 4) duplicate analyses of the same population of cases.

\section{Study quality}

The quality of each study was assessed using the following questions. 1) Was the phenotype of COPD defined by spirometry? 2) Were cases and controls in case-control studies or individuals with different genotypes in population-based studies matched on ethnicity? 3) Did the study control for cigarette smoking? 4) Did the authors test for Hardy-Weinberg equilibrium (HWE)?

The quality of a study was not a factor for inclusion, except when cases and controls were derived from different countries, as mentioned above. The quality questions were used to define subgroups of studies for further analysis.

\section{Data analysis}

For studies that defined COPD using both spirometry and physician diagnosis, the spirometric definition was used. Using the categorical outcome of COPD, separate analyses were performed for the PI SZ and PI MS genotypes. In each analysis, the summary effect estimate was calculated using the random effects method of DERSIMONIAN and LAIRD [15]. The Qstatistic was used to test for heterogeneity among studies.

Funnel plots and weighted regression were used to assess publication bias [16]. For the PI MS genotype, subgroup analyses were performed based on study design, use of spirometric criteria to define COPD, and adjustment for cigarette smoking. In a sensitivity analysis, each study was individually removed and the OR recalculated to determine the stability of the summary effect estimate.

Studies that measured FEV1 (\% predicted) as a continuous outcome were analysed separately. A summary difference in mean FEV1 between PI MM individuals and PI MS individuals was calculated, using the random-effects model [15].

\section{RESULTS \\ Study eligibility}

The literature search yielded 1,125 references, of which 119 were reviewed in detail (fig. 1). The 21 studies included in the meta-analysis are listed in tables 1-3 [12, 17-36]. Seventeen case-control or cross-sectional studies reported the categorical outcome of COPD in PI MS versus PI MM individuals; of these, six also included PI SZ individuals in the study. Seven studies included a total of 23 PI SS individuals, yet a total of only four affected PI SS individuals was found [12, 22, 24, 27-29, 34]. Due to the small numbers, an analysis of PI SS individuals was not performed. Six studies measured FEV1 (\% pred) as a continuous outcome in PI MS heterozygotes. Only one study measured FEV1 in PI SZ and PI SS individuals, so a metaanalysis of the continuous outcome in PI SZ and PI SS subjects could not be performed [12].

Of the 119 papers retrieved for detailed evaluation, the most frequently excluded studies were those that examined COPD risk in PI MZ heterozygotes only ( $n=30$; fig. 1) [37-66]. Other

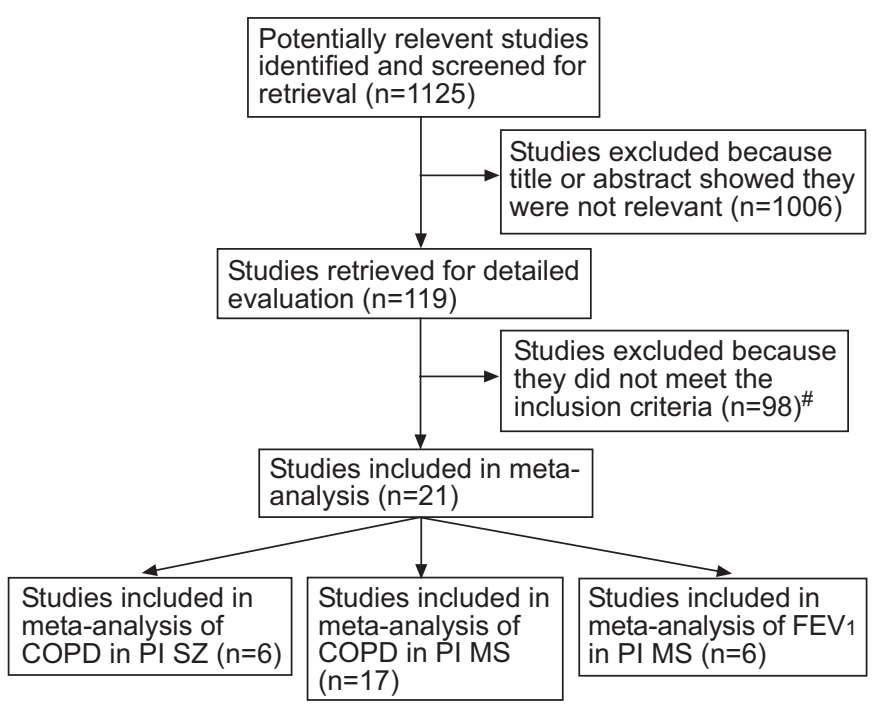

FIGURE 1. Flow diagram of study selection for the meta-analyses. COPD: chronic obstructive pulmonary disease; PI: protease inhibitor; FEV1: forced expiratory volume in one second. \#: see text for details of excluded studies. 


\begin{tabular}{|c|c|c|c|c|c|}
\hline \multirow{3}{*}{$\begin{array}{l}\text { TABLE } 1 \\
\text { 1st Author } \\
\text { [ref.] }\end{array}$} & \multicolumn{5}{|c|}{$\begin{array}{l}\text { Case-control studies of chronic obstructive } \\
\text { pulmonary disease risk in protease inhibitor (PI) } \\
\text { MS and PI SZ individuals }\end{array}$} \\
\hline & \multirow{2}{*}{$\begin{array}{c}\text { PFT } \\
\text { diagnosis }\end{array}$} & \multirow{2}{*}{$\begin{array}{l}\text { Matched } \\
\text { ethnicity }\end{array}$} & \multirow{2}{*}{$\begin{array}{l}\text { Adjusted for } \\
\text { smoking }\end{array}$} & Cases & Controls \\
\hline & & & & \multicolumn{2}{|c|}{ PI MS/PI SZ/PI MM } \\
\hline FAGERHOL [22] & $\mathrm{N}$ & \# & $\mathrm{N}$ & $7 / 1 / 135$ & $14 / 1 / 268$ \\
\hline TALAMO [35] & Y & N & $\mathrm{N}$ & 8/--/84 & 8/--/94 \\
\hline KUEPPERS [26] & Y & \# & N & 12/--/138 & 6/--/193 \\
\hline BARNETT [18] & Y & Y & $\mathrm{N}$ & 6/--/87 & $5 /--/ 81$ \\
\hline Cox [21] & N & Y & N & $7 /--/ 101$ & $57 /--/ 644$ \\
\hline KuEPPERS [27] & Y & N & Y & 5/--/97 & 8/--/98 \\
\hline LocHON [29] & $\mathrm{N}$ & $\#$ & $\mathrm{~N}$ & $2 /--/ 21$ & $25 /--/ 231$ \\
\hline Аввоud [17] & Y & N & N & $5 / 1 / 42$ & 0/0/26 \\
\hline BARTMANN [19] & N & $\#$ & N & $34 / 18 / 429$ & $42 / 1 / 583$ \\
\hline LIEBERMAN [28] & $\mathrm{N}$ & Y & N & 75/2/595 & $110 / 5 / 1213$ \\
\hline Poller [33] & N & \# & N & 9/--/137 & 10/--/130 \\
\hline SANDFORD [34] & Y & Y & Y & 16/--/163 & $7 /--/ 66$ \\
\hline
\end{tabular}

excluded studies lacked an appropriate control group $(n=13)$ [6-10, 67-74]; measured PI type by a suboptimal method $(n=13)$ [74-86]; were reviews, editorials or conference proceedings $(n=10)$ [79, 87-95]; measured AAT level as a proxy for genotype $(n=9)[85,87,96-102]$; grouped together multiple variant genotypes $(n=8)$ [103-110]; used radiographic outcomes or pulmonary function tests other than FEV1 $(n=6)$ [111-116]; did not report FEV1 as a per cent of predicted $(n=4)$ [103, 107, 117, 118]; defined COPD based on self-report or based on autopsy findings $(n=4)$ [117, 119-121]; studied families or children only $(n=4)[106,122-124]$; assessed other rare alleles $(n=3)[94,125,126]$; analysed the same cases as another study $(n=2)[127,128]$; or reported allele frequencies rather than genotypes $(n=1)$ [129]. Some studies were excluded for more than one reason. Of the four studies that reported FEV1 in absolute volumes, rather than as a per cent predicted, only one would not have been excluded by other criteria [118]. Therefore, a separate analysis of these papers could not be performed.

\section{Quality determination}

Tables 1-3 list the characteristics of the 21 included studies. In nine studies, COPD was defined by explicit pulmonary function criteria $[12,17,18,20,26,27,32,34,35]$. A physician's diagnosis was used in the other eight categorical studies. The clinical assessment may have included spirometry, but the authors did not provide specific diagnostic criteria.

Of the 21 studies in the analyses, 13 were conducted in the USA and Canada, two nations with ethnically diverse populations. To control for this, five of these studies restricted their analyses to Caucasians only [20, 21, 28, 31, 34], and one study matched cases and controls by ethnicity [18]. Eight studies were done in Europe [12, 19, 22-24, 26, 29, 33]. Ethnic diversity is presumed to be less in these populations, although none of the authors specifically addressed this issue.

Seven studies adjusted for cigarette smoking, using a variety of epidemiological methods [12, 20, 23, 25, 27, 32, 34]. KuEPPERS et al. [27] matched cases and controls by their smoking histories, i.e. nonsmokers, moderate smokers and heavy smokers. GIRARD et al. [23] matched by smoking status as well. The study by HALL et al. [25] was restricted to nonsmokers. Ostrow et al. [32] stratified subjects by smoking status (smokers versus nonsmokers), while CHAN-YEUNG et al. [20] used three strata (nonsmokers, ex-smokers and current smokers). The studies by SANDFORD et al. [34] and DAHL et al. [12] used logistic regression to adjust for smoking history.

In only one paper, the authors reported testing for HWE [12]. In this study, the observed genotype frequencies were consistent with HWE. The majority of papers fulfilled two or fewer of the four pre-determined quality criteria. The studies by CHAN-YEUNG et al. [20] and SANDFORD et al. [34] each met three criteria, and the study by Dahl et al. [12] was the only one to contain all four quality measures.

\section{PI SZ compound heterozygotes}

The six case-control and cross-sectional studies that examined COPD risk in PI SZ individuals are shown in tables 1 and 2. In the pooled analysis (fig. 2), there were a total of 42 PI SZ compound heterozygotes, of whom 27 had COPD. The summary OR for COPD in PI SZ individuals compared with PI MM was significantly elevated at 3.26 (95\% CI: 1.24-8.57). Although formal testing was not statistically significant ( $Q$ test: Chi-squared (5 degrees of freedom): $6.87 ; p=0.23$ ), clinical heterogeneity was still possible among these observational

\section{TABLE 2 Cross-sectional studies of chronic obstructive pulmonary disease (COPD) risk in protease inhibitor (PI) MS and PI SZ individuals}

\begin{tabular}{|c|c|c|c|c|c|c|}
\hline 1st Author [ref.] & $\begin{array}{c}\text { PFT } \\
\text { diagnosis }\end{array}$ & $\begin{array}{l}\text { Matched } \\
\text { ethnicity }\end{array}$ & $\begin{array}{l}\text { Adjusted for } \\
\text { smoking }\end{array}$ & $\begin{array}{l}\text { PI MS COPD/ } \\
\text { Total PI MS }\end{array}$ & $\begin{array}{c}\text { PI SZ COPD/ } \\
\text { Total PI SZ }\end{array}$ & $\begin{array}{c}\text { PI MM COPD/ } \\
\text { Total PI MM }\end{array}$ \\
\hline Matzen [30] & $\mathrm{N}$ & $\mathrm{N}$ & $\mathrm{N}$ & $6 / 60$ & & $27 / 427$ \\
\hline Chan-Yeung [20] & Y & Y & Y & $7 / 89$ & & $98 / 1006$ \\
\hline Ostrow [32] & Y & $\mathrm{N}$ & Y & $1 / 26$ & & $13 / 330$ \\
\hline Gulsvik [24] & $\mathrm{N}$ & $\#$ & $\mathrm{~N}$ & $14 / 60$ & $1 / 3$ & $123 / 1054$ \\
\hline Dahl [12] & Y & $\#$ & Y & $73 / 456$ & $4 / 10$ & $1053 / 7018$ \\
\hline
\end{tabular}




\begin{tabular}{|c|c|c|c|c|c|c|}
\hline 1st Author [ref.] & Matched ethnicity & Adjusted for smoking & PI MS & Mean FEV $1 \%$ pred & PI MM & Mean FEV $1 \%$ pred \\
\hline Webb [36] & $\mathrm{N}$ & $\mathrm{N}$ & 30 & 101 & 395 & 92 \\
\hline Hall [25] & N & Y & 14 & 105 & 14 & 107 \\
\hline Morse [31] & Y & N & 208 & 98.2 & 2637 & 96.0 \\
\hline \multirow[t]{2}{*}{ Ostrow [32] } & N & Y & $14^{+}$ & 99.5 & $104^{+}$ & 98.9 \\
\hline & & & $12^{\S}$ & 97.7 & $226^{\S}$ & 92.2 \\
\hline Dahl [12] & $\#$ & $\mathrm{~N}^{*}$ & 459 & 90 & 7037 & 90 \\
\hline
\end{tabular}

studies. Therefore, a random effects model was used for the analysis. The funnel plot of OR versus standard error was symmetric, and Egger's test was negative for publication bias $(\mathrm{p}=0.98)$. In the sensitivity analysis, removing the BARTMANN et al. [19] study from the meta-analysis reduced the OR to a value that was not significantly $>1$. However, the new OR remained within the $95 \%$ CI of the overall effect estimate shown in figure 2. Removing any other study did not substantially change the summary OR. Due to the small number of individuals and studies, no subgroup analyses were performed.

\section{PI MS heterozygotes}

Twelve case-control and five cross-sectional studies examined risk of COPD in PI MS heterozygotes compared with PI MM individuals (tables 1 and 2). Only three studies showed a significantly increased risk for PI MS heterozygotes [24, 26, 28]. The pooled analysis (fig. 3) found a small, but significant elevation in risk (OR: 1.19, 95\% CI: 1.02-1.38). Heterogeneity among studies was unlikely ( $Q$ test: Chi-squared (16 degrees of freedom): $14.82 ; \mathrm{p}=0.54$ ).

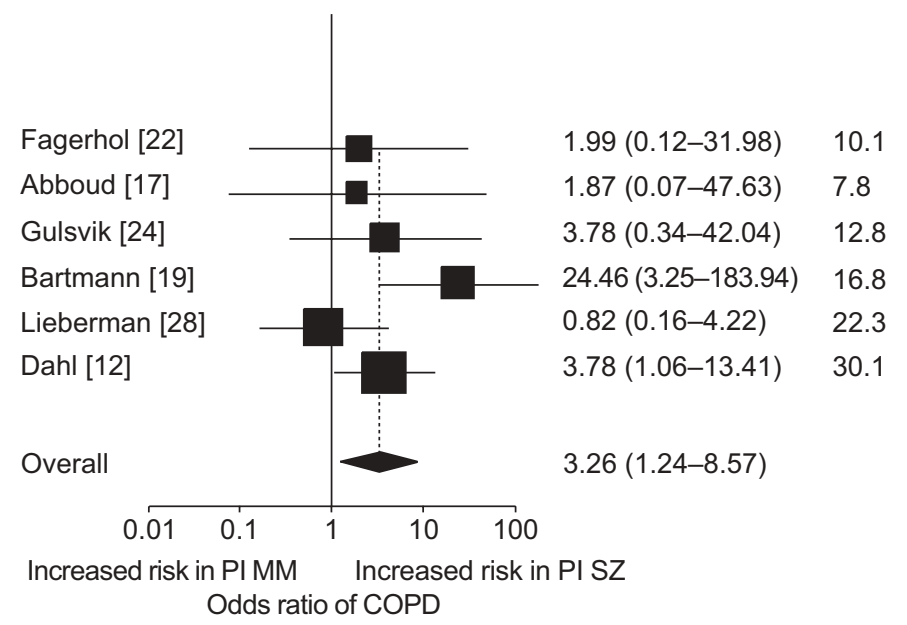

FIGURE 2. Cross-sectional and case-control studies reporting risk of chronic obstructive pulmonary disease (COPD) in protease inhibitor (PI) SZ compound heterozygotes. Box sizes are proportional to inverse-variance weights. Lines represent $95 \%$ confidence intervals $(\mathrm{Cl})$. Three columns of data represent study, OR $(95 \% \mathrm{Cl})$ and \% weight, respectively.
Subgroup analyses of the PI MS categorical studies are shown in figure 4 . The five cross-sectional studies had a summary OR of 1.28 (95\% CI: $0.87-1.88)$, similar to the summary OR of 1.19 (95\% CI: 0.97-1.47) in the 12 case-control studies. The effect estimate (OR) for the studies that used spirometry to define COPD was 1.09 (95\% CI: 0.87-1.35) and for the studies that adjusted for cigarette smoking was 1.02 (95\% CI: 0.81-1.28).

The funnel plot of OR versus standard error showed fewer studies than expected with an OR higher than the summary measure. Publication bias would be expected to have the opposite effect, studies with higher OR might be more frequently published. Egger's test showed no statistical evidence of publication bias $(p=1.0)$. The summary OR was not significantly changed when each study was individually removed in the sensitivity analysis.

Table 3 details the six studies that measured FEV1 (\% pred) in both PI MS and PI MM individuals. The study by Ostrow et al. [32] reported mean FEV1 values stratified by smoking status.
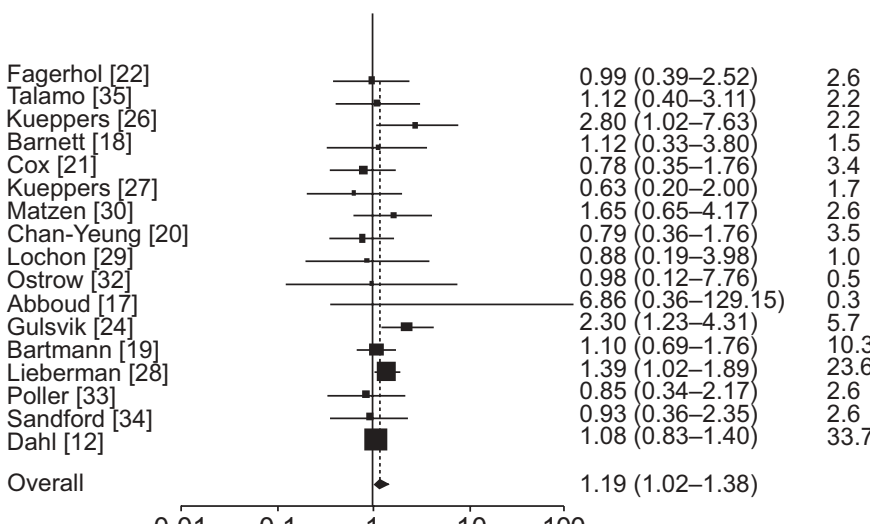

Increased risk in PI MM Increased risk in PI MS

Odds ratio of COPD

FIGURE 3. Cross-sectional and case-control studies of chronic obstructive pulmonary disease (COPD) risk in protease inhibitor (PI) MS heterozygotes. Box sizes are proportional to inverse-variance weights. Lines represent $95 \%$ confidence intervals (Cl). Three columns of data represent study, OR (95\% Cl) and \% weight, respectively. 


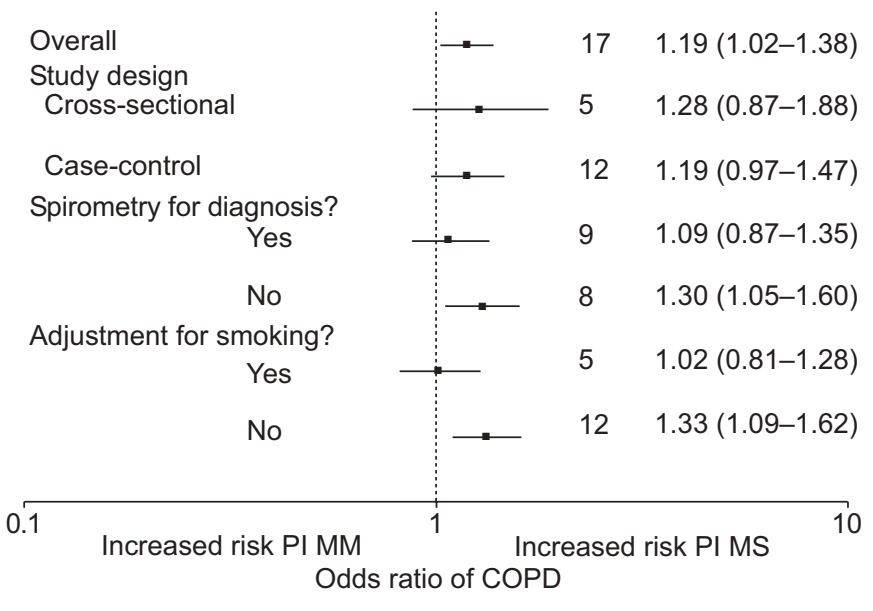

FIGURE 4. Subgroup analysis of cross-sectional and case-control studies reporting risk of chronic obstructive pulmonary disease (COPD) in protease inhibitor (PI) MS heterozygotes. Three columns of data represent subgroup, studies (n) and odds ratio (95\% confidence intervals), respectively.

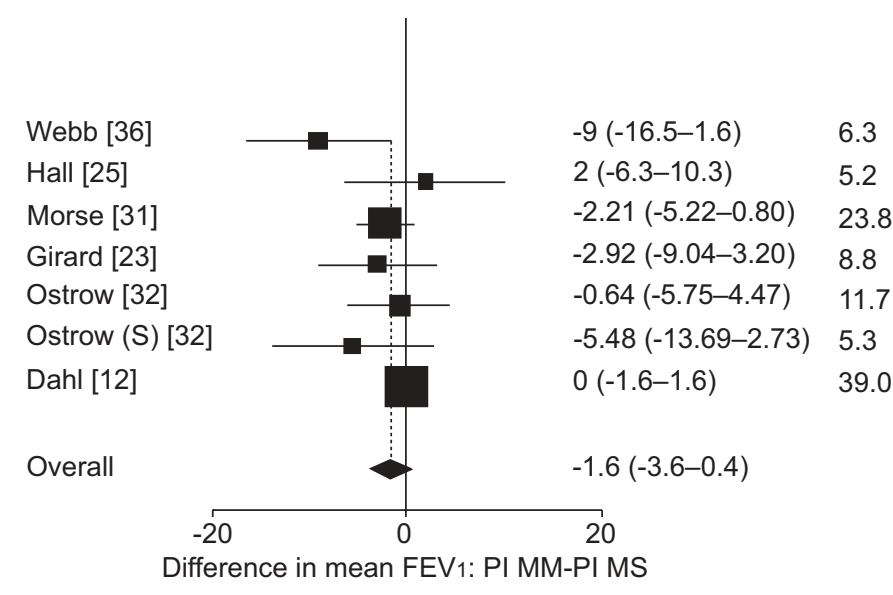

FIGURE 5. Studies reporting spirometry in protease inhibitor (PI) MS heterozygotes. Mean difference is calculated by subtracting the mean forced expiratory volume in one second ( $\mathrm{FEV}_{1}$; \% predicted) in protease inhibitor (PI) MS individuals from the mean $\mathrm{FEV}_{1}$ in PI MM individuals. Box sizes are proportional to inverse-variance weights. Lines represent $95 \%$ confidence intervals (Cl). Three columns of data represent study, difference in mean $\mathrm{FEV}_{1}(95 \% \mathrm{Cl})$ and \% weight, respectively.

Each stratum was entered separately into the pooled analysis. The meta-analysis of difference in mean FEV1 (\% pred) between PI MM and PI MS individuals is shown in figure 5. The mean FEV1 (\% pred) was lower in the PI MS heterozygote group in only one of these studies [25]. Overall, there was no difference in mean FEV1 (\% pred) between PI MM and PI MS individuals (difference in mean FEV1: PI MM-PI MS=-1.61 \% pred; 95\% CI: -3.59-0.38). Heterogeneity was possible among these studies ( $Q$ test: Chi-squared (6 degrees of freedom): 8.56; $\mathrm{p}=0.20)$.

The funnel plot of difference in mean FEV1 versus standard error revealed fewer than expected studies finding a greater mean FEV1 in PI MM individuals. Egger's test did not reveal significant evidence of publication bias $(p=0.14)$. In the sensitivity analysis, removing the study by DAHL et al. [12] led to a lower mean FEV1 in PI MM as compared with PI MS individuals.

\section{DISCUSSION}

In a meta-analysis of studies examining COPD in PI SZ compound heterozygotes, a three-fold elevation in COPD risk due to the PI SZ genotype was found. The CI was broad, but the increased OR was statistically significant. Due to the lack of available data, an analysis of mean FEV1 in PI SZ individuals or an analysis of PI SS homozygotes could not be performed. In a meta-analysis of cross-sectional and case-control studies, a small, but statistically significant increase in risk for COPD amongst PI MS heterozygotes was found. In subgroup analyses aggregating studies that adjusted for smoking or defined COPD based on spirometry, the risk due to the PI MS genotype was not significantly elevated. In addition, studies measuring pulmonary function did not reveal a difference in FEV1 between PI MS and PI MM individuals.

The finding of a three-fold elevated risk in the PI SZ individuals is not surprising, since the PI SZ genotype has been considered a risk factor for COPD, based on case series and registry data. However, the recent ATS statement on AAT deficiency concludes that the PI SZ genotype only confers an elevated risk in cigarette smokers, and that the risk in nonsmokers is not increased [13]. Due to the limited number of subjects with smoking information, it was not possible to calculate separate OR's for PI SZ smokers and nonsmokers. Additional research is warranted with careful characterisation of phenotype and smoking history in the PI SZ study subjects.

After correction for smoking, PI MS was not associated with COPD risk. Nevertheless, the discrepancy in the results found in the analyses of overall COPD risk and FEV1 in PI MS individuals requires further investigation. The potential risk increase found in the categorical studies was not corroborated by the FEV1 results. If all PI MS individuals were at an increased risk for COPD, then a lower lung function among these individuals as a group would be expected. Airflow obstruction, defined as a reduction in FEV1, is a hallmark of COPD and is central to most diagnostic criteria [130]. The different results for the analyses of COPD risk and of FEV1 could be consistent with an increased risk only in a subgroup of PI MS individuals. Due to the different methods used to control for smoking in the various studies, this hypothesis could not be formally tested. Alternatively, the discrepancy in results could reflect a small risk increase in all PI MS individuals, which was not detected in the spirometry studies, due to differences in subject ascertainment or sampling, incomplete adjustment for smoking status, or biased estimates in the case-control studies, due to such factors as population stratification.

Although statistical testing did not reveal evidence of publication bias, the funnel plots in both PI MS analyses showed asymmetry, with a deficiency of studies with a stronger effect estimate than the pooled OR. The small numbers of studies in these analyses most likely explains this finding. A study that found an increased risk of COPD or lower lung 
function in PI MS heterozygotes would not be expected to go unreported.

The small number of studies reporting FEV1 in PI MS individuals is partly a result of the current authors' inclusion criterion that required studies to report FEV1 as a percentage of the predicted value. This requirement was intended to control for potentially important covariates in the measurement of lung function, since commonly used prediction equations account for age, sex, and height [131]. There were not enough available studies reporting FEV1 in absolute volumes to perform a separate meta-analysis. It is under speculation as to whether differences in FEV1 should be adjusted for COPD diagnosis. Unfortunately, none of the authors presented the FEV1 levels stratified by COPD diagnosis, which would be necessary to perform an adjusted analysis. However, as most of the studies were community-based studies (evidenced by the normal mean FEV1 levels in these studies) it is unlikely that removing the minority of individuals with COPD will change the overall results.

The overall study quality was found to be quite variable. Although this could be a potential limitation to the present analysis, it is an inevitable consequence of pooled analyses of observational studies. All meta-analyses are subject to limitations due to the methods used in the original studies. Without data on cigarette smoking in each enrolled individual, it could not be assured that the studies adequately addressed this important risk factor. Consequently, the pooled analysis may be subject to residual confounding or an unmeasured genotype-by-environment interaction. None of the studies explicitly addressed population stratification, so the meta-analysis could not be protected from spurious results arising from stratification within the individual studies.

In the analyses of the PI MS genotype, the COPD risk was not increased in the minority of studies that controlled for smoking, but this does not completely exclude the possibility that there may be an increased risk of COPD in at least a subset of PI MS individuals. With an estimated 16 million PI MS carriers in the USA and 26 million in Europe [132], the overall impact on COPD may not be trivial. Further study is warranted to confirm whether this increased risk may be present.

It was found that the risk of COPD is approximately tripled in PI SZ compound heterozygotes. The risk increase in PI SZ individuals was higher than the risk previously estimated for PI MZ heterozygotes (OR: 2.31) [14], although the confidence intervals overlapped. However, because of the rarity of the PI SZ genotype, its overall effect on COPD risk in the population is likely to be small.

In conclusion, due to the small numbers of protease inhibitor SZ compound heterozygotes sampled in individual studies, further research to determine risk in subgroups (e.g. cigarette smokers) will require more focused sampling of protease inhibitor SZ subjects. Protease inhibitor SZ individuals who come to attention through symptoms or screening should be advised that they are at an increased risk for the development of chronic obstructive disease, although not to the same degree as protease inhibitor $\mathrm{ZZ}$ individuals.

\section{ACKNOWLEDGEMENTS}

The authors would like to thank C. Ramsey for assistance with translation from French.

\section{REFERENCES}

1 Cox DW. Alpha1-antitrypsin deficiency. In: Scriver CR, Beaudet AL, Sly WS, Valle D, eds. The metabolic and molecular bases of inherited disease. 4th Vol. 8th Edn. New York, McGraw-Hill; 2001:5559-5584.

2 Blanco I, Bustillo EF, Rodriguez MC. Distribution of alpha1-antitrypsin PI S and PI Z frequencies in countries outside Europe: a meta-analysis. Clin Genet 2001; 60: 431-441.

3 Blanco I, Fernandez E, Bustillo EF. Alpha-1-antitrypsin PI phenotypes $\mathrm{S}$ and $\mathrm{Z}$ in Europe: an analysis of the published surveys. Clin Genet 2001; 60: 31-41.

4 Hutchison DC. Alpha 1-antitrypsin deficiency in Europe: geographical distribution of Pi types $\mathrm{S}$ and Z. Respir Med 1998; 92: 367-377.

5 Seixas S, Garcia O, Trovoada MJ, Santos MT, Amorim A, Rocha J. Patterns of haplotype diversity within the serpin gene cluster at 14q32.1: insights into the natural history of the alpha1-antitrypsin polymorphism. Hum Genet 2001; 108: 20-30.

6 Larsson C, Dirksen H, Sundstrom G, Eriksson S. Lung function studies in asymptomatic individuals with moderately (Pi SZ) and severely (Pi Z) reduced levels of alpha1-antitrypsin. Scand J Respir Dis 1976; 57: 267-280.

7 Gishen P, Saunders AJ, Tobin MJ, Hutchison DC. Alpha 1-antitrypsin deficiency: the radiological features of pulmonary emphysema in subjects of Pi type $\mathrm{Z}$ and $\mathrm{Pi}$ type SZ: a survey by the British Thoracic Association. Clin Radiol 1982; 33: 371-377.

8 Hutchison DC, Tobin MJ, Cook PJ. Alpha 1 antitrypsin deficiency: clinical and physiological features in heterozygotes of Pi type SZ. A survey by the British Thoracic Association. Br J Dis Chest 1983; 77: 28-34.

9 Turino GM, Barker AF, Brantly ML, et al. Clinical features of individuals with $\mathrm{PI}^{*} \mathrm{SZ}$ phenotype of alpha 1-antitrypsin deficiency. Alpha 1-Antitrypsin Deficiency Registry Study Group. Am J Respir Crit Care Med 1996; 154: 1718-1725.

10 Seersholm N, Kok-Jensen A. Intermediate alpha 1antitrypsin deficiency PiSZ: a risk factor for pulmonary emphysema? Respir Med 1998; 92: 241-245.

11 Brantly ML, Wittes JT, Vogelmeier CF, Hubbard RC, Fells GA, Crystal RG. Use of a highly purified alpha 1antitrypsin standard to establish ranges for the common normal and deficient alpha 1-antitrypsin phenotypes. Chest 1991; 100: 703-708.

12 Dahl M, Tybjaerg-Hansen A, Lange P, Vestbo J, Nordestgaard BG. Change in lung function and morbidity from chronic obstructive pulmonary disease in alpha1-antitrypsin MZ heterozygotes: a longitudinal study of the general population. Ann Intern Med 2002; 136: 270-279.

13 American Thoracic Society/European Respiratory Society Statement: Standards for the diagnosis and management of individuals with alpha-1 antitrypsin deficiency. Am J Respir Crit Care Med 2003; 168: 818-900. 
14 Hersh CP, Dahl M, Ly NP, Berkey CS, Nordestgaard BG, Silverman EK. Chronic obstructive pulmonary disease in alpha 1-antitrypsin PI MZ heterozygotes: a meta-analysis. Thorax 2004; 59: 843-849.

15 DerSimonian R, Laird N. Meta-analysis in clinical trials. Control Clin Trials 1986; 7: 177-788.

16 Egger M, Smith GD, Schneider M, Minder C. Bias in meta-analysis detected by a simple, graphical test. BMJ 1997; 315: 629-634.

17 Abboud RT, Rushton JM, Grzybowski S. Interrelationships between neutrophil elastase, serum alpha, -antitrypsin, lung function and chest radiography in patients with chronic airflow obstruction. Am Rev Respir Dis 1979; 120: 31-40.

18 Barnett TB, Gottovi D, Johnson AM. Protease inhibitors in chronic obstructive pulmonary disease. Am Rev Respir Dis 1975; 111: 587-593.

19 Bartmann K, Fooke-Achterrath M, Koch G, et al. Heterozygosity in the Pi-system as a pathogenetic cofactor in chronic obstructive pulmonary disease (COPD). Eur J Respir Dis 1985; 66: 284-296.

20 Chan-Yeung M, Ashley MJ, Corey P, Maledy H. Pi phenotypes and the prevalence of chest symptoms and lung function abnormalities in workers employed in dusty industris. Am Rev Respir Dis 1978; 117: 239-245.

21 Cox DW, Hoeppner VH, Levison H. Protease inhibitors in patients with chronic obstructive pulmonary disease: the alpha-antitrypsin heterozygote controversy. Am Rev Respir Dis 1976; 113: 601-606.

22 Fagerhol MK, Hauge HE. Serum Pi types in patients with pulmonary diseases. Acta Allergol 1969; 24: 107-114.

23 Girard F, Aug F, Camara M, et al. [Pulmonary abnormality and alpha 1-antitrypsin heterozygote deficiency in a working population (author's transl)]. Bull Eur Physiopathol Respir 1978; 14: 11-22.

24 Gulsvik A, Fagerhol MK. Alpha 1-antitrypsin phenotypes and obstructive lung disease in the city of Oslo. Scand J Respir Dis 1979; 60: 267-274.

25 Hall WJ, Hyde RW, Schwartz RH, et al. Pulmonary abnormalities in intermediate alpha-1-antitrypsin deficiency. J Clin Invest 1976; 58: 1069-1077.

26 Kueppers F, Donhardt A. Obstructive lung disease in heterozygotes for alpha-1 antitrypsin deficiency. Ann Intern Med 1974; 80: 209-212.

27 Kueppers F, Miller RD, Gordon H, Hepper NG, Offord K. Familial prevalence of chronic obstructive pulmonary disease in a matched pair study. Am J Med 1977; 63: 336-342.

28 Lieberman J, Winter B, Sastre A. Alpha 1-antitrypsin Pitypes in 965 COPD patients. Chest 1986; 89: 370-373.

29 Lochon B, Vercaigne D, Lochon C, et al. [Pan-lobular emphysema: relationship with serum alpha-1-antitrypsin levels, Pi phenotype and the HLA system (author's transl)]. Nouv Presse Med 1978; 7: 1167-1170.

30 Matzen RN, Bader PI, Block WD. alpha1-Antitrypsin deficiency in clinic patients. Ann Clin Res 1977; 9: 88-92.

31 Morse JO, Lebowitz MD, Knudson RJ, Burrows B. Relation of protease inhibitor phenotypes to obstructive lung diseases in a community. N Engl J Med 1977; 296: 1190-1194.
32 Ostrow DN, Manfreda J, Dorman T, Cherniack RM. Alpha1-antitrypsin phenotypes and lung function in a moderately polluted northern Ontario community. Can Med Assoc J 1978; 118: 669-672.

33 Poller W, Meisen C, Olek K. DNA polymorphisms of the alpha 1-antitrypsin gene region in patients with chronic obstructive pulmonary disease. Eur J Clin Invest 1990; 20: $1-7$.

34 Sandford AJ, Weir TD, Spinelli JJ, Pare PD. Z and S mutations of the alpha1-antitrypsin gene and the risk of chronic obstructive pulmonary disease. Am J Respir Cell Mol Biol 1999; 20: 287-291.

35 Talamo RC, Langley CE, Levine BW, Kazemi H. Genetic vs. quantitative analysis of serum alpha 1 -antitrypsin. $N$ Engl J Med 1972; 287: 1067-1069.

36 Webb DR, Hyde RW, Schwartz RH, Hall WJ, Condemi JJ, Townes PL. Serum alpha 1-antitrypsin variants. Prevalence and clinical spirometry. Am Rev Respir Dis 1973; 108: 918-925.

37 Bruce RM, Cohen BH, Diamond EL, et al. Collaborative study to assess risk of lung disease in Pi MZ phenotype subjects. Am Rev Respir Dis 1984; 130: 386-390.

38 Cooper DM, Hoeppner V, Cox D, Zamel N, Bryan AC, Levison $\mathrm{H}$. Lung function in alpha1-antitrypsin heterozygotes (Pi type MZ). Am Rev Respir Dis 1974; 110: 708-715.

39 Duncan PE, Griffin JP. Physiological studies in a large sibship with antitrypsin deficiency. Br J Dis Chest 1975; 69: 107-117.

40 Eriksson S, Moestrup T, Hagerstrand I. Liver, lung and malignant disease in heterozygous (Pi MZ) alpha1antitrypsin deficiency. Acta Med Scand 1975; 198: 243-247.

41 Eriksson S, Lindell SE, Wiberg R. Effects of smoking and intermediate alpha 1-antitrypsin deficiency (PiMZ) on lung function. Eur J Respir Dis 1985; 67: 279-285.

42 Galdston M, Melnick EL, Goldring RM, Levytska V, Curasi CA, Davis AL. Interactions of neutrophil elastase, serum trypsin inhibitory activity, and smoking history as risk factors for chronic obstructive pulmonary disease in patients with MM, MZ, and ZZ phenotypes for alphaantitrypsin. Am Rev Respir Dis 1977; 116: 837-846.

43 Gelb AF, Klein E, Lieberman J. Pulmonary function in nonsmoking subjects with alpha1 antitrypsin deficiency (MZ phenotype). Am J Med 1977; 62: 93-98.

44 Haack DG. Interactions of neutrophil elastase, serum trypsin inhibitory activity, and smoking history as risk factors for chronic obstructive pulmonary disease in patients with MM, MZ, and ZZ phenotypes for alpha1antitrypsin. Am Rev Respir Dis 1978; 117: 812-813.

45 Horne SL, Tennent RK, Cockcroft DW, Cotton DJ, Dosman JA. Pulmonary function in $\mathrm{Pi} M$ and $\mathrm{MZ}$ grainworkers. Chest 1986; 89: 795-799.

46 Horne SL, Cockcroft DW, Dosman JA. Possible protective effect against chronic obstructive airways disease by the GC2 allele. Hum Hered 1990; 40: 173-176.

47 Horton FO 3rd, Mackenthun AV, Anderson PS Jr, Patterson CD, Hammarsten JF. Alpha 1 antitrypsin heterozygotes (Pi type MZ). A longitudinal study of the risk of development of chronic air flow limitation. Chest 1980; 77: 261-264. 
48 Kabiraj MU, Simonsson BG, Groth S, Bjorklund A, Bulow K, Lindell SE. Bronchial reactivity, smoking, and alpha1-antitrypsin. A population-based study of middleaged men. Am Rev Respir Dis 1982; 126: 864-869.

49 Kambe M, Morishita K, Tsubokura T, et al. A study on the lung function in alpha 1-antitrypsin-deficient (PiMZ) patients. Hiroshima J Med Sci 1993; 42: 41-45.

50 Khoury MJ, Beaty TH, Newill CA, Bryant S, Cohen BH. Genetic-environmental interactions in chronic airways obstruction. Int J Epidemiol 1986; 15: 65-72.

51 Klasen EC, Biemond I, Laros CD. Alpha 1-antitrypsin deficiency and the flaccid lung syndrome. The heterozygote controversy. Clin Genet 1986; 29: 211-215.

52 Klayton R, Fallat R, Cohen AB. Determinants of chronic obstructive pulmonary disease in patients with intermediate levels of alpha-antitrypsin. Am Rev Respir Dis 1975; 112: 71-75.

53 Kozarevic D, Laban M, Budimir M, et al. Intermediate alpha1-antitrypsin deficiency and chronic obstructive pulmonary disease in Yugoslavia. Am Rev Respir Dis 1978; 117: 1039-1043.

54 Lam S, Abboud RT, Chan-Yeung M, Rushton JM. Neutrophil elastase and pulmonary function in subjects with intermediate alpha1-antitrypsin deficiency (MZ phenotype). Am Rev Respir Dis 1979; 119: 941-951.

55 Larsson C, Eriksson S, Dirksen H. Smoking and intermediate alpha1-antitrypsin deficiency and lung function in middle-aged men. BMJ 1977; 2: 922-925.

56 Madison R, Zelman R, Mittman C. Inherited risk factors for chronic lung disease. Chest 1980; 77: 255-257.

57 Madison R, Mittman C, Afifi AA, Zelman R. Risk factors for obstructive lung disease. Am Rev Respir Dis 1981; 124: 149-153.

58 McDonagh DJ, Nathan SP, Knudson RJ, Lebowitz MD. Assessment of alpha-1-antitrypsin deficiency heterozygosity as a risk factor in the etiology of emphysema. Physiological comparison of adult normal and heterozygous protease inhibitor phenotype subjects from a random population. J Clin Invest 1979; 63: 299-309.

59 Mittman C. The PiMZ phenotype: is it a significant risk factor for the development of chronic obstructive lung disease? Am Rev Respir Dis 1978; 118: 649-652.

60 Pride NB, Tattersall SF, Pereira RP, Hunter D, Blundell G. Lung distensibility and airway function in intermediate alpha 1-antitrypsin deficiency (PiMZ). Chest 1980; 77: 253-255.

61 Roberts A, Kagan A, Rhoads GG, Pierce JA, Bruce RM. Antitrypsin and chronic obstructive pulmonary disease among Japanese-American men. Chest 1977; 72: 489-491.

62 Seersholm N, Wilcke JT, Kok-Jensen A, Dirksen A. Risk of hospital admission for obstructive pulmonary disease in alpha(1)-antitrypsin heterozygotes of phenotype PiMZ. Am J Respir Crit Care Med 2000; 161: 81-84.

63 Shigeoka JW, Hall WJ, Hyde RW, et al. The prevalence of alpha-antitrypsin heterozygotes (Pi MZ) in patients with obstructive pulmonary disease. Am Rev Respir Dis 1976; 114: 1077-1084.

64 Siekmeier R, Schiller-Scotland CF. Convective gas mixing, airway dimensions and lung function parameters in patients homo- or heterozygote for hereditary alpha1antitrypsin deficiency. Toxicol Lett 1998; 96-97: 325-333.
65 Tarjan E, Magyar P, Vaczi Z, Lantos A, Vaszar L. Longitudinal lung function study in heterozygous PiMZ phenotype subjects. Eur Respir J 1994; 7: 2199-2204.

66 Tattersall SF, Pereira RP, Hunter D, Blundell G, Pride NB. Lung distensibility and airway function in intermediate alpha 1-antitrypsin deficiency (Pi MZ). Thorax 1979; 34: 637-646.

67 Bruun-Petersen K, Bruun-Petersen G, Dahl R, et al. Alpha 1-antitrypsin alleles in patients with pulmonary emphysema, detected by DNA amplification (PCR) and oligonucleotide probes. Eur Respir J 1992; 5: 531-537.

68 Mittman C, Barbela T, Lieberman J. Antitrypsin deficiency and abnormal protease inhibitor phenotypes. Arch Environ Health 1973; 27: 201-206.

69 Mittman C, Lieberman J, Rumsfeld J. Prevalence of abnormal protease inhibitor phenotypes in patients with chronic obstructive lung disease. Am Rev Respir Dis 1974; 109: 295-296.

70 Piitulainen E, Sveger T. Effect of environmental and clinical factors on lung function and respiratory symptoms in adolescents with alpha1-antitrypsin deficiency. Acta Paediatr 1998; 87: 1120-1124.

71 Sandford AJ, Chagani T, Weir TD, Connett JE, Anthonisen NR, Pare PD. Susceptibility genes for rapid decline of lung function in the lung health study. Am J Respir Crit Care Med 2001; 163: 469-473.

72 Stockley RA. alpha 1-Antitrypsin phenotypes in cor pulmonale due to chronic obstructive airways disease. Q J Med 1979; 48: 419-428.

73 Wencker M, Marx A, Konietzko N, Schaefer B, Campbell EJ. Screening for alpha1-Pi deficiency in patients with lung diseases. Eur Respir J 2002; 20: 319-324.

74 Varpela E, Salorinne Y. Respiratory disease profile in 22 patients with alpha 1-antitrypsin deficiencies. Scand J Respir Dis Suppl 1974; 89: 251-260.

75 Alvarez-Granda L, Cabero-Perez MJ, Bustamante-Ruiz A, Gonzalez-Lamuno D, Delgado-Rodriguez M, GarciaFuentes M. PI SZ phenotype in chronic obstructive pulmonary disease. Thorax 1997; 52: 659-661.

76 Cohen BH, Ball WC Jr, Bias WB, et al. A geneticepidemiologic study of chronic obstructive pulmonary disease. I. Study design and preliminary observations. Johns Hopkins Med J 1975; 137: 95-104.

77 Guenter CA, Welch MH, Ferguson S, Henderson L, Hammarsten JF. Alpha-1-antitrypsin deficiency: heterozygosity, intermediate levels, and pulmonary disease. Chest 1971; 59: Suppl. 16S+.

78 Gupta SP, Pande JN, Guleria JS. Pulmonary emphysema and alpha-1 antitrypsin deficiency. Indian J Med Res 1977; 66: 127-132.

79 Janus ED. Alpha 1-antitrypsin Pi types in COPD patients. Chest 1988; 94: 446-447.

80 Larson RK, Barman ML, Kueppers F, Fudenberg HH. Genetic and environmental determinants of chronic obstructive pulmonary disease. Ann Intern Med 1970; 72: 627-632.

81 Mittman C, Lieberman J, Marasso F, Miranda A. Smoking and chronic obstructive lung disease in alpha-1-antitrypsin deficiency. Chest 1971; 60: 214-221.

82 Morse JO, Lebowitz MD, Knudson RJ, Burrows B. A community study of the relation of alpha1-antitrypsin 
levels to obstructive lung diseases. N Engl J Med 1975; 292: 278-281.

83 Shah AC, Dixit SD, Billimoria FP, Merchant HC, Unawala J. Occurrence of alpha 1-antitrypsin deficiency in normal healthy Indians and in patients with various pulmonary diseases. J Indian Med Assoc 1983; 81: 79-82.

84 Szczeklik A, Stankowska K, Frydecka I. Cardiopulmonary function in 1 -antitrypsin heterozygotes exposed to severe air pollution. Am Rev Respir Dis 1973; 107: 289-291.

85 Talamo RC, Allen JD, Kahan MG, Auste KF. Hereditary alpha-1-antitrypsin deficiency. N Engl J Med 1968; 278: 345-351.

86 Welch MH, Reinecke ME, Hammarsten JF, Guenter CA. Antitrypsin deficiency in pulmonary disease: the significance of intermediate levels. Ann Intern Med 1969; 71: 533-542.

87 Amin M. The role of alpha 1-antitrypsin in generating chronic obstructive pulmonary disorder. Respirology 2001; 5: Suppl. 6, S39-S43.

88 Berend N. Epidemiological survey of chronic obstructive pulmonary disease and alpha-1-antitrypsin deficiency in Australia. Respirology 2001; Suppl. 6, S21-S25.

89 Camara M, Martin JP. [Alpha 1-antitrypsin deficiency and its repercussions in pulmonary pathophysiology (author's transl)]. Bull Eur Physiopathol Respir 1978; 14: 91-124.

90 Hutchison DC. Homozygous and heterozygous alpha-1antitrypsin deficiency: prevalence in pulmonary emphysema. Proc R Soc Med 1976; 69: 130-131.

91 Kauffmann F. Genetics of chronic obstructive pulmonary diseases. Searching for their heterogeneity. Bull Eur Physiopathol Respir 1984; 20: 163-210.

92 Lieberman J, Colp C. A role for intermediate, heterozygous alpha 1-antitrypsin deficiency in obstructive lung disease. Chest 1990; 98: 522-523.

93 Mittman C, Barbela T, Lieberman J. Alpha 1 -antitrypsin deficiency as an indicator of susceptibility to pulmonary disease. J Occup Med 1973; 15: 33-38.

94 Shim YS. Epidemiological survey of chronic obstructive pulmonary disease and alpha-1 antitrypsin deficiency in Korea. Respirology 2001; Suppl. 6, S9-S11.

95 Zhu YJ. Epidemiological survey of chronic obstructive pulmonary disease and alpha-1-deficiency in China. Respirology 2001; 6: S13-S15.

96 Fallat R, Powell M, Kueppers F, Nadel J, Murray J. Chronic obstructive pulmonary disease with intermediate alpha-1-antitrypsin deficiency. Chest 1971; 59: Suppl. 20S+.

97 Hepper NG, Black LF, Gleich GJ, Kueppers F. The prevalence of alpha 1-antitrypsin deficiency in selected groups of patients with chronic obstructive lung disease. Mayo Clin Proc 1969; 44: 697-710.

98 Lieberman J, Mittman C, Schneider AS. Screening for homozygous and heterozygous alpha 1-antitrypsin deficiency. Protein electrophoresis on cellulose acetate membranes. JAMA 1969; 210: 2055-2060.

99 Lieberman J. Heterozygous and homozygous alphaantitrypsin deficiency in patients with pulmonary emphysema. N Engl J Med 1969; 281: 279-284.
100 Smith JP Jr, Falk GA, Siskind GW. Serum immunoglobulins and alpha-1-antitrypsin: variation with clinical type of chronic obstructive pulmonary disease. Chest 1971; 59: Suppl: 17S+.

101 Stevens PM, Hnilica V, Johnson PC, Bell RC. Pathophysiology of hereditary emphysema. Chest 1971 59: Suppl:19S.

102 Sveger T. Plasma protease inhibitors in alpha 1antitrypsin-deficient children. Pediatr Res 1985; 19: 834-835.

103 Buist AS, Sexton GJ, Azzam AM, Adams BE. Pulmonary function in heterozygotes for alpha,-antitrypsin deficiency: a case-control study. Am Rev Respir Dis 1979; 120: 759-766.

104 Cohen BH, Ball WC Jr, Brashears S, et al. Risk factors in chronic obstructive pulmonary disease (COPD). Am J Epidemiol 1977; 105: 223-232.

105 Colp C, Talavera W, Goldman D, Green J, Multz A, Lieberman J. Profile of bronchospastic disease in Puerto Rican patients in New York City. A possible relationship to alpha 1-antitrypsin variants. Arch Intern Med 1990; 150: 2349-2354.

106 Corbo GM, Forastiere F, Agabiti N, et al. Passive smoking and lung function in alpha(1)-antitrypsin heterozygote schoolchildren. Thorax 2003; 58: 237-241.

107 Gerblich AA, Kleinerman J, Rynbrandt DJ, Chester EH, Ihrig J. Pi-Z phenotypes in a pulmonary clinic. Their prevalence and physiologic state. Am J Clin Pathol 1978; 69: 509-513.

108 Kueppers F, Fallat R, Larson RK. Obstructive lung disease and alpha-1-antitrypsin deficiency gene heterozygosity. Science 1969; 165: 899-901.

109 Kueppers F. Alpha-1-antitrypsin: 1. Evidence for two genes causing low concentrations in serum; 2. Association of heterozygosity and chronic obstructive lung disease. Chest 1971; 59: Suppl. 15S+.

110 Pierre F, Pham QT, Mur JM, Chau N, Martin JP. Respiratory symptoms and pulmonary function in 871 miners according to Pi phenotype: a longitudinal study. Eur J Epidemiol 1988; 4: 39-44.

111 Fallat RJ, Powell MR, Kueppers F, Lilker E. 133 Xe ventilatory studies in 1-antitrypsin deficiency. J Nucl Med 1973; 14: 5-13.

112 Hepper NG, Muhm JR, Sheehan WC, Kueppers F, Offord KP. Roentgenographic study of chronic obstructive pulmonary disease by alpha1-antitrypsin phenotype. Mayo Clin Proc 1978; 53: 166-172.

113 Johnson TF, Reisman RE, Arbesman CE, Mattar AG, Murphey WH. Obstructive airway disease associated with heterozygous alpha-1-antitrypsin deficiency. J Allergy Clin Immunol 1976; 58: 69-75.

114 Laros KD, Biemond I, Klasen EC. The flaccid lung syndrome and alpha 1-protease inhibitor deficiency. Chest 1988; 93: 831-835.

115 Lebowitz MD, Knudson RJ, Morse JO, Armet D. Closing volume and flow volume abnormalities in alpha(1)antitrypsin phenotype groups in a community population. Am Rev Respir Dis 1978; 117: 179-181.

116 Ostrow DN, Cherniack RM. The mechanical properties of the lungs in intermediate deficiency of 1 -antitrypsin. Am Rev Respir Dis 1972; 106: 377-383. 
117 Cole RB, Nevin NC, Blundell G, Merrett JD, McDonald JR, Johnston WP. Relation of alpha-1-antitrypsin phenotype to the performance of pulmonary function tests and to the prevalence of respiratory illness in a working population. Thorax 1976; 31: 149-157.

118 de Hamel FA, Carrell RW. Heterozygous alpha 1antitrypsin deficiency: a longitudinal lung function study. N Z Med J 1981; 94: 407-410.

119 Silva GE, Sherrill DL, Guerra S, Barbee RA. A longitudinal study of alpha1-antitrypsin phenotypes and decline in FEV1 in a community population. Chest 2003; 123: $1435-1440$.

120 Stjernberg N, Beckman G, Beckman L, Nystrom L, Rosenhall L. Alpha-1-antitrypsin types and pulmonary disease among employees at a sulphite pulp factory in northern Sweden. Hum Hered 1984; 34: 337-342.

121 Sutinen S, Koistinen J, Paakko P. A necropsy study of Pi phenotypes, emphysema, and smoking. Acta Pathol Microbiol Immunol Scand [A] 1985; 93: 183-188.

122 Silverman EK, Province MA, Rao DC, Pierce JA, Campbell EJ. A family study of the variability of pulmonary function in alpha 1-antitrypsin deficiency. Quantitative phenotypes. Am Rev Respir Dis 1990; 142: 1015-1021.

123 Vance JC, Hall WJ, Schwartz RH, Hyde RW, Roghmann KJ, Mudholkar GC. Heterozygous alpha-1antitrypsin deficiency and respiratory function in children. Pediatrics 1977; 60: 263-272.

124 von Ehrenstein OS, von Mutius E, Maier E, et al. Lung function of school children with low levels of alpha1antitrypsin and tobacco smoke exposure. Eur Respir J 2002; 19: 1099-1106.

125 Bencze K, Sabatke L, Fruhmann G. Alpha 1-antitrypsin: the PiMM subtypes. Do they play a role in development of chronic obstructive pulmonary diseases? Chest 1980; 77: 761-63.

126 Seyama K. State of alpha 1-antitrypsin deficiency in Japan. Respirology 2000; 6: S35-S38.

127 Dahl M, Nordestgaard BG, Lange P, Vestbo J, TybjaergHansen A. Molecular diagnosis of intermediate and severe alpha(1)-antitrypsin deficiency: MZ individuals with chronic obstructive pulmonary disease may have lower lung function than MM individuals. Clin Chem 2001; 47: 56-62.

128 Miller RD, Hepper NG, Kueppers F, Gordon H, Offord KP. Host factors in chronic obstructive pulmonary disease in an upper Midwest rural community. Design, case selection, and clinical characteristics in a matchedpair study. Mayo Clin Proc 1976; 51: 709-715.

129 Kauffmann F, Kleisbauer JP, Cambon-De-Mouzon A, et al. Genetic markers in chronic air-flow limitation. A genetic epidemiologic study. Am Rev Respir Dis 1983; 127: 263-269.

130 Pauwels RA, Buist AS, Calverley PM, Jenkins CR, Hurd SS. Global strategy for the diagnosis, management, and prevention of chronic obstructive pulmonary disease. NHLBI/WHO Global Initiative for Chronic Obstructive Lung Disease (GOLD) Workshop summary. Am J Respir Crit Care Med 2001; 163: 1256-1276.

131 Crapo RO, Morris AH, Gardner RM. Reference spirometric values using techniques and equipment that meet ATS recommendations. Am Rev Respir Dis 1981; 123: 659-664.

132 de Serres FJ. Worldwide racial and ethnic distribution of alpha1-antitrypsin deficiency: summary of an analysis of published genetic epidemiologic surveys. Chest 2002; 122: $1818-1829$. 